\title{
US and European Integration prior to 1968
}

\author{
Nguyen Thi Thuy Hang*
}

\begin{abstract}
This paper surveys the history of the United States policy towards European integration from 1945 up to 1968 before President Nixon came into office. Drawing on a detailed analysis of the documents mostly obtainable from the official websites of the US Department of State, the US National Archives, and the EU Historical Archives, the paper argues that it was the European geopolitical and economic context after the Second World War and the United States national interests which moulded this country's pro-European integration policy. Thus, the paper will begin with an analysis of the search for global influence between the United States and the Soviet Union before examining how the United States redefined its core interests in recognition of the Soviet threat. Then, it will explore the role that the United States played in reconstructing Western European economy and defending it physically. Also, it is argued that the United States and Western Europe took concerted action together to create the European Coal and Steel Community (ECSC), European Economic Community (EEC), and the European Atomic Energy Community (EAEC or Euratom), the very first supranational institutions which have made the European integration process irreversible. It will be concluded that the vitality of the European integration project depended on US economic and political capital for its success.
\end{abstract}

Keywords: European integration, the Nixon administration, Western Europe, the Marshall Plan, NATO.

It is of vital importance to the United States that European recovery be continued to ultimate success...If Europe failed to recover the peoples of these countries might be driven to a philosophy of despair - the philosophy which contends that their basic wants can be met only by the surrender of their basic rights to totalitarian control. Such a turn of events would constitute a shattering blow to peace and stability in the world.

Truman, 1947

* Hang Nguyen is a doctoral candidate at the School of Urban, Global and Social Studies, the Royal Melbourne Institute of Technology (RMIT), Australia. She is conducting a research project on US policy towards European integration under the Nixon administration. Her research interests include US foreign policy, US-EU relations, European integration, Europeanisation, Globalisation and Vietnam's politics and foreign policy. Email: s3374642@student.rmit.edu.au 
I will say here and now, on this Day of Independence, that the United States will be ready for a Declaration of Interdependence, that we will be prepared to discuss with a united Europe the ways and means of forming a concrete Atlantic partnership, a mutually beneficial partnership between the new union now emerging in Europe and the old American Union founded here 175 years ago.

All this will not be completed in a year, but let the world know it is our goal.

Kennedy, 1962

The US views and attitudes towards European economic and political integration from 1945 up to 1968 before President Nixon took possession of the White House were generally supportive. The Truman, Eisenhower, Kennedy and Johnson administrations' enthusiasm for European moves towards integration were driven by their calculations of US security and strategic interests in the Cold War setting. On the surface, the US's pro-European integration policy appears to be the story of a US foreign policy seeking to promote peace in the world politics. However, a closer examination suggests that the path of this foreign policy was carefully designed by US administrations that always placed US national interests in the first priority in their foreign policy agenda.

To understand changes and continuity in US policy towards European integration in general, it is essential to review US policy in Western Europe from 1945 to 1968. This historical excursion will show why and how the US administrations prior to 1968 had supported Western European integration. Henceforth, this paper will begin with a description of US and Soviet efforts to fill the power vacuums. That the US leadership developed and defined the Soviet threat after the Second World War had a profound impact on European integration. Then, the paper analyses how the economic aid and political supports offered by the US administrations helped to pacify much of Europe. While defending the peoples in Europe not only against the Soviet Union but also against themselves, the United States established a grand alliance with Western Europe and laid European integration as a cornerstone in its foreign policy design. It will be concluded that the United States had been a crucial force to drive the European economic and political integration process. It was undeniable that the European integration process evolved from within Europe; however, such evolution would be hardly smooth without concerted efforts made by US administrations. 


\section{Filling power vacuums}

Apart from a war-weakened Europe, world politics in the post-1945 era was characterised by the search for global influence between the United States and the Soviet Union, popularly termed the Cold War ${ }^{1}$. Germany, Italy, and Japan were all defeated. This left vacuums of power in the world politics landscape. The United Kingdom was "nearly bankrupt, dependent and unable to police its empire, was reduced to a resentful second-rate power"; France was suffering from political instability and incapable of mustering international respect ${ }^{2}$. Nationalist movements in the colonial world broke out, seeking independence and struggling to "make the world less Europe-centered"." The United States and the Soviet Union, equally enthusiastic to realize their universal visions of the post-war world and expand their respective influence, sought to fill power vacuums left by both the defeat of Germany, Italy, and Japan and the decline of the United Kingdom and France ${ }^{4}$. Nonetheless, the United States and the Soviet Union had many conflicts over occupation policies in Germany, Italy, Japan, Australia, and Korea.

After the Second World War, only the United States and the Soviet Union were able to challenge one another for influence in Europe and for the capacity to establish the parameters of the post-war world. The United States aimed to contain further influence of the Soviet Union in Europe by developing free market capitalism on this continent. From the US perspective, this would contribute to the rehabilitation of West European economies and their political stability. By tying these economies to its economy, the United States would enhance its opportunity to expand its influence in the worlds.

As the Soviet Union consolidated their control over the territory that had been liberated from Nazi occupation by the Red Army, the relationship between the two wartime allies became worse. The consolidation of Moscow-controlled communist governments in East and Central Europe, the communist coup in

Malone R., “The Contest for World Domination”, Trumpet, September/October, 2005, <https:// www.thetrumpet.com/article/1703.20.76.0/middle-east/the-contest-for-world-domination>, 1405 2014.

2 Paterson T. G., On Every Front: The Making and Unmaking of the Cold War, New York: W.W. Norton \& Company, 1993, p. 25.

Ibid, p. 26.

Ibid, p. 25-26.

Johnson C., The Sorrow of Empire: Militarism, Secrecy, and the End of the Republic, New York: Metropolitan Books, 2004. 
Prague in February 1948, and the Soviet blockade of West Berlin put an end to the Grand Allies established during the Second World War. On the US side, the Truman Doctrine was announced as a bulwark against further Soviet expansion in Europe and elsewhere:

The world is not static, and the status quo is not sacred. But we cannot allow changes in the status quo in violation of the Charter of the United Nations by such methods as coercion, or by such subterfuges as political infiltration. In helping free and independent nations to maintain their freedom, the United States will be giving effect to the principles of the Charter of the United Nations ${ }^{6}$.

In addition to that, the United States positively responded to the European initiative to create a North Atlantic Treaty Organization (NATO).

The Parties to this Treaty...seek to promote stability and well-being in the North Atlantic area...

Article 5

The Parties agree that an armed attack against one or more of them in Europe or America shall be considered an attack against them ${ }^{7}$.

By 1950 the background for the Cold War had been established: two superpowers, the United States and the Soviet Union, each was supported by groups of allies, confronted each other in the middle of Europe. To recall Dean Acheson's words, then undersecretary of the US Department of State: "not since Rome and Carthage, had there been such a polarization of power on this earth". The multi-polar system of the 1930s was replaced by a bipolar structure. Yet, it should be noted that this bipolar world does not mean that the two poles were equal in power. There were basic asymmetries between the United States and the Soviet Union from the early post-war years. The United States had unchallenged economic power. To compensate its economic weakness relative to the United States, the Soviet Union sought to sustain its military strength and impose ideological and political dominance in the sphere of influence that it had set up in Eastern Europe. Indeed, in their struggle for global influence, the United States

“Truman Doctrine”: President Harry S. Truman’s Address Before a Joint Session of Congress, March 12, 1947, Avalon Project, <http://avalon.law.yale.edu/20th_century/trudoc.asp>, 30092013.

7 The North Atlantic Treaty, Washington D.C., April 4, 1949, <http://www.nato.int/cps/en/natolive/ official_texts_17120.htm>, 30092013.

8 Duiker W. J., Spielvogel J. J., World history, volumes II: Since 1500, 6th ed., Boston: Wadsworth, 2010, p. 772. 
and the Soviet Union employed a wide range of means such as a massive and expensive arms race, propaganda campaigns and especially the creation of rival alliances and the extension of military and economic aid to client states and wouldbe client states?

\section{Perpetual interests}

Lord Palmerston underlined in 1848 that core national interests could be seen as the "eternal" and ultimate justification for national policy ${ }^{10}$. With the presence of Soviet power, Washington had considered which regions and issues the United States needed to care about. Miscamble argues Roosevelt's administration "failed to appreciate that their national interests were tied up with either complementing or assuming the long time British role of preventing Eurasia's domination by a single power. President Franklin Roosevelt and the United States did not fight the war to become the 'balancer' in international politics. They fought it primarily to defeat the Axis powers and to preserve their way of life ${ }^{11}$."

However, in the recognition of the threat to the United States and its institutions that a powerful Soviet Union represented, Washington had fundamentally redefined its core interests. Leffler highlights that "the essentials of American grand strategy called for a Eurasian land mass free from the domination of a single hostile power (or coalition of adversaries) and a world trading system hospitable to the unrestricted movement of goods and capital ${ }^{12}$." Explicitly, this meant that a recovered Europe would certainly help the US national interests avoid being profoundly affected as shown in the Department of State's report titled "Certain aspect of the European recovery problem from the United States standpoint" in July 1947. The report shows that the United States had important economic interest in Europe. Europe had been the US market and main source of supply for a wide range of products and services to the people of the United States.

$9 \quad$ Powaski R. E., The Cold War: The United States and the Soviet Union 1917-1991, New York: Oxford University Press, 1998, p. ix.

10 Ridley J., Lord Palmerston, London: Constable, 1970, p. 334.

11 Miscamble W. D., Debating American Grand Strategy after Major War: Roosevelt, Truman and the Development of Postwar Grand Strategy, Elsevier Limited, 2009, p. 554.

12 Leffler M. P., “American Grand Strategy from World War to Cold War 1940-1950”, in Kennedy P., Hitchcock W. I., eds., From War to Peace: Altered Strategic Landscapes in the Twentieth Century, New Haven, New York, 2000, p. 58-59. 
Furthermore, the report affirmed that security in Europe had been strategically important to US security. This underpinned US determination to defend Europe from being disintegrated:

The broad pattern of our foreign policy, including the confidence we have placed in the United States, has assumed the continuation in Europe of a considerable number of free states subservient to no great power, and recognizing their heritage of civil liberties and personal responsibility and determined to maintain this heritage ${ }^{13}$.

To sum up, the core national interests of the US were physical security, the promotion of democracy, economic prosperity and world order. It also should be noted that the very first priority was given to US influence. These interests have been somewhat reconfirmed in President Barack Obama's Nobel Peace Prize lecture in Oslo in December 2009: "The United States of America has helped underwrite global security for more than six decades with the blood of our citizens and the strength of our arms ... We have done so out of an enlightened self-interest because we seek a better future for our children and grandchildren ${ }^{14}$." The pursuit of such "enlightened self-interest" has been the essential element of US national policies in general and US policy towards European unity in particular.

\section{Essential motives}

US politicians' public statements about their support for European integration fairly reflected US foreign policy; but the motives for such US assistance were much more complicated. An analysis of the themes emerging from the documentary research has revealed five main reasons why the United States supported European integration:

Firstly, from its own experience of development from thirteen colonies to a successful federal model and market economy, the United States highly hoped to conduct its economic and political system in Europe through the course of European integration. The endeavour to realize this high hope was apparently

\footnotetext{
13 Department of State's report "Certain Aspects of the European Recovery Problem from the United States Standpoint", July 23, 1947, <http://www.trumanlibrary.org/whistlestop/study_collections/ marshall/large/documents/pdfs/6-1.pdf\#zoom=100>, 18012013.

14 Obama B., A Just and Lasting Peace, Nobel Peace Prize 2009 lecture, Oslo, December 10, 2009, <http:// nobelprize.org/nobel_prizes/peace/laureates/2009/obama-lecture_en.html>, 18012013.
} 
expressed in US politicians' addresses. For instance, in his speech before the OEEC council (Organization for European Economic Cooperation) calling for greater integration in Europe in Paris on October 31, 1949, Paul Hoffman, the head of the Economic Cooperation Administration lectured US lessons on the Europeans as follows:

The substance of such integration would be the formation of a single large market within which quantitative restriction on the movements of goods, monetary barriers to the flow of payments and, eventually, all tariffs are permanently swept away. The fact that we have in the United States a single market of 156 million consumers has been indispensable to the strength and efficiency of our economy. The creation of a permanent, freely trading area, comprising 270 million consumers in Western Europe would have a multitude of helpful consequences. It would accelerate the development of large-scale, low-cost production industries. It would make the effective use of all resources easier, the stifling of healthy competition more difficult ${ }^{15}$.

Supporting the move for economic integration from within Western Europe, the United States wanted to apply such a pattern in the region. This would ensure not only economic, socio-political stability on the continent but also the US's long-term economic development. US enterprises would see in Western Europe not merely a chance to share the fruits of an expanding economy but also the opportunity to have a part in the exploitation of a great new mass market on this continent.

Secondly, the United States held the view that an economically integrated Europe would be more efficient and rational. This would definitely be in the US's interests. President Eisenhower indicated that a "Europe cannot attain the towering material stature possible to its peoples' skills and spirit so long as it is divided by patchwork territorial fences" was unable to solve its problems ${ }^{16}$. In the spirit of an old age axiom "united we stand, divided we died", he also pointed out that "once united, the farms and factories of France and Belgium, the foundries of Germany, the rich farmlands of Holland and Denmark, the skilled labour of Italy, will produce miracles for the common good ${ }^{17}$." In addition, European integration would help to prevent movements of nationalism and wars in Europe. The United States profited

15 Hoffman P., Hoffman's Speech before the OEEC Council Calling for Greater Integration in Europe, October 31, 1949, <http://www.hum.leiden.edu/history/eu-history/historical/schuman.html>, 16 092013.

16 Eisenhower J., General Ike: A Personal Reminiscence, Norwalk: Easton Press, 2003, p. 230.

17 Ibid. 
more from dealing with a united European partner than with individual larger and smaller European nations. The question "Who do I call if I want to speak to Europe?" raised by Henry Kissinger, US top diplomat under presidents Richard Nixon and Gerald Ford in the 1970s, implicitly meant it was necessary for Europe to be united to speak in one voice. This eventually produced a more efficient and rationale European partner for the United States in international politics.

Thirdly, European unity in the security and economic areas would lighten the burden put on the United States after the Second World War. This was probably the reason for Clayton's recommendation for a three-year grant only to help Europe to rebuild its economy based on a European economic federation, an unthinkable measure in the United States itself. Eisenhower firmly held that European unity "would mean early dependence from American aid and other Atlantic countries" as he really sought to decrease US federal expenditure, which required a massive deduction in defence expenditure. ${ }^{18}$ President Kennedy, the Republican successor, also concerned about the US's increasing negative balance of payment shared the view that a united Europe should be able to play a greater role in the mutual defence, do more for developing countries and together with the United States, lower the trade barriers and solve economic disputes:

A united Europe will be capable of playing a greater role in the common defense, of responding more generously to the needs of poorer nations, of joining with the United States and others in lowering trade barriers, resolving problems of commerce, commodities, and currency, and developing coordinated policies in all economic, political, and diplomatic areas. We see in such a Europe a partner with whom we can deal on a basis of full equality in all the great and burdensome tasks of building and defending a community of free nations ${ }^{19}$. (Kennedy 1962).

US concern about reducing its economic and military burden could be solved partly with "a solid, healthy and confident Europe" as clearly stated by President Eisenhower: "If with our moral and material assistance, the free European nations could attain a similar integration, our friends would be strengthened, our own economies improved, and the laborious NATO machinery of mutual defense vastly simplified ${ }^{20 ”}$.

18 Eisenhower J., General Ike: A Personal Reminiscence, Norwalk: Easton Press, 2003, p. 232.

19 Kennedy J. F., Address at the Independence Hall in Philadelphia, July 4, 1962, <http://www.jfklibrary. org/Asset-Viewer/Archives/JFKWHA-113-001.aspx >, 29072015.

$20 \quad$ Eisenhower, (note 16) p. 232. 
Fourthly, a strong Europe could help to contain the Soviet Union. The United States was determined to contain the expansion of communism in Europe. The United States sought to prevent the scenario in which the peoples of Western European nations would not have resisted the Soviet Union's invasion very much because they were disappointed with capitalism and democracy and considered communism as a fairer and better system. France and Italy, nations in Western Europe, had strong communist parties. Communists had leading roles to play in the resistance in these two countries in the Second World War. Communists had also done well in democratic elections in France and Italy. The United States diminished any possibilities that communist parties in such nations were able to gain power, either through the ballots or revolutions, as this would eventually lead to the further expansion of the Soviet Union's sphere of influence.

Acting on our own, by ourselves, we cannot establish justice throughout the world; we cannot insure its domestic tranquillity, or provide for its common defense, or promote its general welfare, or secure the blessings of liberty to ourselves and our posterity. But joined with other free nations, we can do all this and more. We can assist the developing nations to throw off the yoke of poverty. We can balance our worldwide trade and payments at the highest possible level of growth. We can mount a deterrent powerful enough to deter any aggression. And ultimately we can help to achieve a world of law and free choice, banishing the world of war and coercion ${ }^{21}$.

In the US perspective, the most effective way to avert those possibilities was to sustain strong US military forces in Western Europe following the Second World War to deal with any potential expansion of communism or the Soviet Union's sphere of influence, and to provide economic assistance to Western European nations to help them reconstruct their infrastructures and economies destroyed by tragic events during the Second World War. This would indicate the superiority of the capitalist system and democracy to the communist system.

The last motive behind US support for European integration is associated with its concern about a Germany in Europe. Seemingly, from the US approach, it was important to restore Germany's industries, as contributions from Germany to the rehabilitation of Europe were crucial. Yet, an industrially restored Germany would accumulate economic might and ultimately military power and political dominance in Europe. Such German dominance was one of the deep roots of the war, which had just devastated Europe as much as Germany and France. The United States held the view that the best solution to the German problem was to

21 Kennedy, (note 19). 
integrate Germany with Western Europe generally and with France particularly. An industrialized Germany in a strong European framework would decisively contribute to preventing future problems with this state.

These motives were central between 1945 and 1950 when the United States promoted the Marshall Plan and the establishment of the North Atlantic Treaty Organization.

\section{Indispensable contributions}

Policymakers in Washington had an intention to guarantee that the United States would have a long-lasting influence on the European continent and continue to shape the future of Europe ${ }^{22}$. US enthusiasm for the creation of a more united Europe was clearly expressed in the European Recovery Program (ERP), or the Marshall Plan aimed at reconstructing the Western European economy, and the establishment of NATO aimed at defending physical security on the continent. Yet, it should be noted that European economic integration was a process evolved from within Western Europe. European leaders designed a plan for the birth of the European Coal and Steel Community (ECSC) and the European Economic Community (EEC) with the hope that economic integration would ensure peace and prosperity on the continent. The United States was interested in their scheme and encouraged European economic unity. US policy ensured that a more united Europe remained friendly to the United States. The Truman, Eisenhower, Kennedy and Johnson administrations between 1945 and 1968 had tried to make the new Europe fit into a wider Atlantic framework. The Marshall Plan and the establishment of NATO were the important contributions of the US leading to the formation of the ECSC and the EEC.

\subsection{The Marshall Plan and European integration}

The U.S. leadership firmly believed that economic recovery in Europe was vital to achieve and sustain stability in the region. From the US view Western Europe was crucial in establishing a stable equilibrium between the United States and the Soviet Union. Even though the United States enjoyed a position of unparalleled

Larres K., Assertive Supremacy and Enlightened Self-interest: The United States and the 'Unity of Europe', Johns Hopkins University, 2009, p. 5. 
military might and great economic and political influence after the immediate Second World War, its leadership, guided by the conviction that no nation could build a safer and better world alone and the realization that there was a strong connection between stability and national security, as one of the concluding remarks underlined in the report completed by the Special "Ad Hoc" Committee of the State-War-Navy Coordinating Committee in 1947: "The United States has need of friends in the world today and particularly needs to take care that other nations do not pass under the influence of any potentially hostile nation ${ }^{23}$ ".

Implicitly, the report affirmed that it was in the interests of the United States to help European and other devastated areas over the period of constructions. The main purpose of US assistance was to support socio-economic stability, prevent political chaos and extremism, contain the spread of communism and orientate foreign countries towards Capitol Hill.

On May 28, 1947 Secretary of State George Marshall made a decision that the US government needed to do something about the situation in Western Europe. Based on the assessments of European circumstances put forth in the reports and memoranda from committees of the State Department which repeatedly described the emergency needs of Western Europe and called for immediate action taken by the United States, it was agreed that these Western European countries, especially Italy and France, were running out of food and fuel supplies for the fall and winter and had insufficient finances to buy such necessities ${ }^{24}$. It was concluded that these Western European countries were unable, by their own efforts, to deal effectively with the major crisis on their soil. Seriously, "a collapse of France and Italy could initiate expanding economic depression and political repercussions throughout Europe and, potentially, over a wide part of the world ${ }^{25}$ ". At the meeting, Acheson

23 Report of the Special 'Ad Hoc' Committee of the State-War-Navy Coordinating Committee, StateWar-Navy Coordinating Committee Files: Series 360, April 21, 1947.

24 Memorandum from Mike Mansfield, Clifford Papers, ca. 1947, Harry S. Truman Library \& Museum, <http://www.trumanlibrary.org/whistlestop/study_collections/marshall/large/documents/ index.php?documentdate=1947-00-00\&documentid=5-9\&pagenumber=>; Charles Kindleberger to Benjamin Cohen, State Department File, Kindleberger Papers, Harry S. Truman Library \& Museum, April 5, 1946, <http://www.trumanlibrary.org/whistlestop/study_collections/marshall/ large/documents/index.php? documentdate=1946-04-05\&documentid=4-6\&pagenumber=1 >; Notes for Acheson speech, "The Economics of Peace”, ca. March 1947. Subject File, J. M. Jones Papers, Harry S. Truman Library \& Museum, <http://www.trumanlibrary.org/whistlestop/study_ collections $/$ marshall/large/documents/index.php?documentdate $=1947-03-00 \&$ documentid=13\&pagenumber=1>, 27122013.

25 Objective Committee, European Recovery Program Basic Document no. 1, October 31, 1947 , <http://www.trumanlibrary.org/whistlestop/study_collections/marshall/large/documents/pdfs/6-3. pdf\#zoom=100>, 29092013. 
recommended that a speech needed to be delivered by Marshall to show the problematic situation in Europe but not to put forth any blueprint for action. After that the speech was prepared by the instructions of Marshall ${ }^{26}$. Secretary of State George Marshall made this speech at the Harvard University on June 5,1947 . This was an official proposal for what was then known as the Marshall Plan, which provided over US $\$ 12.5$ billion (equivalent to roughly US $\$ 60$ billion today) for rebuilding Western Europe. He made clear in his address that Europe was definitely in a political and economic chaos and a response from the United States was needed urgently to cope with the problem facing the Europeans. He emphasized that the aid for European reconstruction of its economy and society was not aimed to fight any nations, but to fight hunger and depression. In the speech it was made clear that a solution had to be set forth by the Europeans and the United States would provide friendly assistance and support for a European practical program. By calling on European governments to design a coordinated aid program on their own, Marshall indicated that Washington wanted Western European countries to come up with a scheme for using the aid. This plan expected to be designed as "a joint effort rather than a hodgepodge of national requests ${ }^{27}$ ".

The Marshall Plan was lauded by Western Europe, as the Europeans understood that a large-scale program entirely funded by the United States could enable them to rebuild European economies, and only the United States was in the position to give them a helping hand. The main requirements for the economic recovery of Europe were reviving industrial and agricultural production, rehabilitating the European transport network, developing facilities for increasing European exchanges, and meeting interim import deficits. Moreover, adopting a federal structure was a condition to receive Marshall Plan aid. Free trade, a customs union, and the reduction of social welfare were included in the list of essential characters the United States gave to Western European governments ${ }^{28}$. Funds were also offered to the Soviet Union and its allies but the conditional terms on economic cooperation and disclosure of information were unacceptable to the Soviet Union ${ }^{29}$.

26 See Hogan M., The Marshall Plan: America, Britain, and the Reconstruction of Western Europe, Cambridge: Cambridge University Press, 1987; Milward A. S., The Reconstruction of Western Europe, 1945-1951, Berkeley and Los Angeles: University of California Press, 1984; Jones J. A., Fifteen Weeks, New York: The Viking Press, 1955; Gimbel J., The Origins of the Marshall Plan, Stanford: Stanford University Press, 1976.

27 Aren J. V. O., Uniting Europe: European Integration and the Post-Cold War World, New York: Rowan \& Littlefield, 2000, p.3.

28 Gilber M., Surpassing Realism: The Politics of European Integration since 1945, New York: Rowman \& Littlefield, 2003, p. 22-23.

29 McMahon R. J., The Cold War: Very Short Introductions, Oxford: Oxford University Press, 2003, p. 30. 
The Soviet Union was suspicious of the US's motivation for aiding European reconstruction. Its leaders even made an accusation that Washington's motive behind the Marshall was to gain control of Europe and penetrate into Moscow's sphere of influence. The US desire for entire European recovery could not be realized as eight countries behind the Iron Curtain, under pressure from the Soviet Union, refused to take part in the European Reconstruction Conference in Paris on July $121947^{30}$. US aid recipients included Austria, Belgium, Denmark, France, West Germany, Great Britain, Greece, Iceland, Ireland, Italy, Luxembourg, the Netherlands, Norway, Sweden, Switzerland and Turkey. These nation-states established the Organization for European Economic Cooperation (OEEC, later the OECD) to coordinate the program based on national needs and make sure it was implemented in consistence with US guidance ${ }^{31}$. The OEEC was the very first of a long line of organizations that contributed to uniting Europe. Although, contrary to US expectations, the OEEC was principally intergovernmental in nature, this was one of the first institutions that helped to enhance the liberalization of trade among the member states, and brought in the ideas of monetary agreements and economic cooperation between Western European countries. European industrial and business practices were modernized on the basis of high-efficiency US models, artificial trade barriers were reduced; and a sense of hope and self-reliance were promoted $^{32}$.

Due to the energetic efforts of President Truman himself and his administration, the Marshall Plan became a reality. The passage of the Marshall Plan was "America's answer to the challenge facing the free world ${ }^{33}$ ". It was ironical that Joseph Stalin was also an important figure behind this reality. President Truman once said that without his "crazy" moves "we never would have had our foreign policy [...] we never could have got a thing from Congress ${ }^{34 "}$.

It is undeniable that the United States was motivated by self-interest in initiating the Marshall Plan. This was expressed, for example, in the declaration

30 Norman A. G., Richard D. B. \& Joseph M. S., America and the Cold War, 1941-1991, California: Praeger Security International, 2010, p.126.

31 Scott S., From War to Wealth: 50 Years of Innovation, Organisation for Economic Co-Operation and Development, 1997, p.16.

32 Eichengreen B., The European Economy since 1945: Coordinated Capitalism and Beyond, New Jersey: Princeton University Press, 2008, p. 62-73.

33 Truman H. S., 1948, Statement by the President upon Signing the Foreign Assistance Act, <http:// trumanlibrary.org/publicpapers/viewpapers.php?pid=1430>, 15122013.

34 Marshall Plan, Chapter section from: Airbridge to Berlin - The Berlin Crisis of 1948, its Origins and Aftermath, by Giangreco D. M., Griffin R. A., 1988, Harry S. Truman Library \& Museum, <http:// www.trumanlibrary.org/whistlestop/BERLIN_A/MARSHALL.HTM>, 29122013. 
96

of Under-Secretary of State for Economic Affairs, William L. Clayton after his fact-finding mission to Europe in May 1947: "It is now obvious that we grossly underestimated the destruction to the European economy by the war... Europe is steadily deteriorating 35 ". He added that "the immediate effects on our domestic economy would be disastrous: markets for our surplus production gone, unemployment, depression, a heavily unbalanced budget on the background of a mountainous war debt. These things must not happen ${ }^{36 "}$. The United States, Clayton concluded, must create a substantial aid program and that "the United States must run this show ${ }^{37 "}$.

By the time the Marshall Plan ended in 1952, industrial production in Western Europe had amounted to $40 \%$ above the pre-war level (Constitutional Rights Foundation 1975, The Marshall Plan for Rebuilding Western Europe). Trade and exports also increased far above what they were before the war. The economy of all recipient states had surpassed pre-war levels and their output in 1951 was 35\% higher than in $1938^{38}$. In the next two decades, the economy of Western Europe continued to grow and prosper extraordinarily. The Marshall Plan was a great success, a contributing factor of European integration since it lifted trade barriers and established institutions to coordinate the economy on a continental level ${ }^{39}$. This ultimately stimulated the whole political reconstruction of Western Europe ${ }^{40}$.

This was also echoed by Herman Van der Wee, a Belgian economic historian. The Marshall Plan, he argued, "gave a new impetus to reconstruction in Western Europe and made a decisive contribution to the renewal of the transport system, the modernization of industrial and agricultural equipment, the resumption of normal production, the raising of productivity, and the facilitating of intraEuropean trade ${ }^{41}$ ". The Marshall Plan indeed was a great success of US foreign policy. It established a firm foundation for the integrative process in Europe:

35 Papayoanou P. A., Power Ties: Economic Interdependence, Balancing, and War, Michigan: University of Michigan Press, 1999, p.132.

$37 \quad$ Ibid.

38 Eichengreen, (note 32) p. 57.

39 Mee C. L., The Marshall Plan: The Launching of the Pax Americana, New York: Simon and Schuster, 1984.

40 Milward A. S., The Reconstruction of Western Europe, 1945-1951, London: Newton, 1984, p. 466.

${ }_{41}$ Van der Wee H., Prosperity and Upheaval: The World Economy, 1945-1980, London: Penguin, 1984, p. 44 . 
The material assistance and the moral encouragement provided by the Marshall Plan brought a powerful new impetus to the campaign for European unity. In fact, it can be said that the American policy of economic aid, coupled with the pressure of the Communist danger, created conditions in which, for the first time, the unification of Europe became a practical possibility ${ }^{42}$.

The success of the Marshall Plan was greater than the United States and Western European people had expected. Perhaps, the biggest benefits brought by the Marshall Plan were intangible. It promoted cooperation and coordination among traditional foes enhancing openness in governments. In addition, it gave the Western Europeans hope and confidence for the future ${ }^{43}$.

The Marshall Plan aid was contingent on Western Europe adopting the liberal ideas of free trade, reduction of protectionism, and easy convertibility of currency. States receiving the Marshall Plan aid and others signed the General Agreement on Tariffs and Trade (GATT) in October 1947. The GATT established rules for trade and states eradicated many trade barriers ${ }^{44}$.

Without this US-sponsored program, it was very unlikely that the Western European economies and polities would have stabilized so quickly. The Marshall Plan has contributed to the creation of a post-war order in Western Europe and transatlantic relations, which have favourably served US core interests. Noticeably, this was a collaborative order in which the Europeans were full partners and could have the greatest voice in their nations' affairs.

\subsection{The formation of NATO and European integration}

Along with the concern for reconstructing the European economy, the US and Western European leaders were worried about gaining power to confront the Soviet Union with superior force and ambitions, especially when the Soviet ambitions were revealed, not by verbalization but through its course of action. In February

42 The Council of Europe, 1949, quoted from Hogan M. J., Blueprint for Recovery, The Marshall Plan Investment in Peace - 50th Anniversary, U.S. Diplomatic Mission to Germany, <http://usa. usembassy.de/etexts/marshall/pam-blu.htm >.

43 Agnew J., Entrikin J. N., The Marshall Plan Today: Model and Metaphor, New York: Routledge, 2014, p. 211.

44 Tipton F. B., Aldrich R., An Economic and Social History of Europe from 1939 to the Present, Baltimore: The John Hopkins University Press, 1987, p. 87. 
1948, a coup d'état was engineered in Prague by the Kremlin and Czechoslovakia was pushed behind the Iron Curtain. Four months later, in June a blockade was imposed on Berlin by the Soviet Union in order to dislodge the Western powers from that city. The Americans and Europeans considered that these events signalled Moscow's overt hostility and aggressive intention and held the view that Europe's economic recovery was impossible in the atmosphere of tension and insecurity. According to the State Department expert, Hickerson, if the Soviet Union was able to topple the anti-communist regime of Czechoslovakia so easily, they could undermine other governments like they did in Czechoslovakia and Czechoslovakia might not be the last target of the Kremlin ${ }^{45}$. In the Truman administration's perspective, after its destruction of the independence and democracy of nations in Eastern and Central Europe and now the fall of free Czechoslovakia in its orbit, the Soviet Union posed a real threat to the other free nations in Europe. In such a crisis situation, both the US and European leaders realized the need to protect Europe physically was as urgent as the need to rebuild this region economically. From the realization that a precondition for European recovery was military security, European leaders started to have conversations on the establishment of an effective European security alliance in February 1947. Though the European leaders expressed their wish to have the involvement of the United States in their alliance, the Truman administration was not prepared to take part in a joint security system with the Europeans, particularly in an election year. On March 17 1948, the United Kingdom, Belgium, the Netherlands, Luxembourg and France signed the Brussels Pact of collective self-defence, which officially created the Western European Union's Defence Organization. Article IV of the Brussels Treaty stated clearly the mechanism of collective defence: "If any of the High Contracting Parties should be the object of an armed attack in Europe, the other High Contracting Parties will, in accordance with the provisions of Article 51 of the Charter of the United Nations, afford the Party so attacked all the military and other aid and assistance in their power ${ }^{46 "}$.

The old isolationism prevailed in US foreign policy making and formulating was weakened after the coup d'état in Prague. In May of 1948, a resolution was proposed by Republican Senator Arthur H. Vandenburg to recommend that the

45 Graebner N. A., Burns R. D., Siracusa J. M., American and the Cold War, 1941-1991: A Realist Interpretation, Vol. 2, California: Praeger, 2010, p. 132.

46 "The Brussels Treaty": Treaty of Economic, Social and Cultural Collaboration and Collective SelfDefence, March 17, 1948, <http://www.nato.int/cps/en/SID-207E2B09-4E1A764B/natolive/ official_texts_17072.htm?>, 23122013. 
United States could join the new European defence pact that would abide by the United Nations charter but not under the control of the Security Council in which the Soviet Union had veto power. The Truman administration approved the Vandenburg Resolution, which "established bipartisan support for American participation in a European system of collective defence" and started to have formal negotiations with the Europeans ${ }^{47}$. France, which had feared expansions from both Germany and the Soviet Union, required the United States to automatically take part in any European wars whether they had been triggered by the Germans or the Russians. However, Washington only accepted the menace that came from the Soviet Union and reminded Paris that Western occupation of Germany would prevent an invasion in France from the Germans. This reflected that Washington's commitment to the European defence system was stemming from its fear of Soviet expansionism and its aim to create a new balance of power. Also, large-scale military assistance from Washington to support the rebuilding of Western Europe's defence capabilities was needed. While European nations preferred individual grants and aid from Washington, the United States refused to provide aid for individual nations and insisted on giving support on the basis of regional coordination. Besides, the question of scope was put on the negotiating table. The Brussels Treaty signatories demanded that membership in the alliance had to be restricted to the members of that treaty and the United States. The US negotiators reminded the Europeans that there was more to be gained from an enlargement of the new alliance with an inclusion of the North Atlantic nations (Canada, Iceland, Denmark, Norway, Ireland, and Portugal). From a geographic strategic view, the combination of these nations' territories would form a bridge between the two shores of the Atlantic Ocean and this would certainly constitute favourable conditions for military action to be taken effectively if it deemed necessary ${ }^{48}$. The United States played a vital role in countering the military power of the Soviet Union and European security was an important condition for European economic recovery, therefore, formal treaty negotiations were concluded shortly on the conditions put forth by the United States. The five Brussels Pact states along with the United States, Canada, Iceland, Denmark, Norway, Ireland, and Portugal signed the North Atlantic Treaty in

47 Graebner, Burns, Siracusa, (note 35) p.134.

48 For outstanding overviews on the creation of NATO, see Lawrence S. K., A Community of Interest: NATO and the Military Assistance Program, 1948-195, Washington, DC: Government Printing, 1980; Lawrence S. K., NATO 1948: The Birth of the Transatlantic Alliance, Lanham: Rowman \& Littlefield, 2007; Escott R., Time of Fear and Hope: The Making of the North Atlantic Treaty, 19471949, Toronto: McClelland \& Stewart, 1977; and Ireland T. P., Creating the Entangling Alliance: The Origins of NATO, Chicago: University of Chicago, 1981. 
April 1949 in Washington to establish a new intergovernmental military alliance. They reached an agreement that any armed attack against one or more of the European state parties or the North American state parties to the North Atlantic Treaty would be seen as an attack against all of them ${ }^{49}$.

The establishment of NATO was part of a wider process of European integration. It critically helped to safeguard freedom and security to support the greater political and economic integration in Western Europe. Lord Hastings Ismay, the first Secretary General of NATO in his lecture on NATO in 1954 recalled: "It became obvious that unless something was done to restore the balance of military and economic power, there was no reason why the States of Western Europe should not also be gobbled up, one by one. But how was this to be done? No single nations could do it alone. It could only be done by combining. It was in that dark hour that the North Atlantic Treaty was conceived and signed ${ }^{50 "}$.

It was undeniable that the United States played a strategic role in the structure of NATO and in the pursuit of its goals, as stated by Lord Hastings Ismay, "to keep the Russians out, the Americans in, and the Germans down ${ }^{51}$." With the US commitment to Western European security, the Europeans could step forward with plans for reconstruction and integration of their economy. As the Cold War escalated and Europe was divided, integration came to be considered as a means by which Europe was able to enhance its security, in close cooperation with the United States, against the Soviet threat and the communism danger. The United States was drawn deeper into European affairs to defend the vulnerable nationstates on this continent. Washington came to be seen as a "zealous champion on European integration ${ }^{52 “}$.

\section{Concerted efforts: the European Coal and Steel Community}

The above-mentioned movements, although remarkable and full of hope, "fell far short of the integrationist objectives of those who sought to escape from national

\footnotetext{
49 The North Atlantic Treaty, (note 7).

50 Hastings I., Lecture on NATO: What It Is and How It Works, November 5, 1954, <http://www. nato.int/cps/en/SID-A63F6257-8D0B59BB/natolive/opinions_17417.htm?selectedLocale>, 2312 2013.

51 Ibid.

52 Dinan D., Ever Closer Union: An Introduction to European Integration, 4th ed., Colorado: Lynne Rienner Publishers, 2010, p. 13.
} 
rivalries ${ }^{53}$. The question of Franco-German relations was unsolved. France, after three German invasions, was still very much concerned with Germany's future and saw European unity as a solution ${ }^{54}$. Washington agreed with Jean Monnet, the key figure behind the formation of the ECSC, on the limits of national sovereignty and the advantages of supra-nationality in Western Europe. According to them, the lessons of modern US history could be applied to war-torn Europe. With the enhancement of interstate trade and the establishment of a single market, the United States had become a prosperous and mighty power. So could Western Europe. In that way, European integration became a crucial part "of a grand design for remaking the Old World in the likeness of the New ${ }^{55}$ ". Put simply, Monnet's idea of eliminating nationalism and developing supra-nationalism in Europe was supported by the United States. Washington wanted France to come up with a supra-national solution to the German problem. In October 1949, then Secretary of State Dean Acheson had a meeting in Washington, D.C. with "the more important American Ambassadors in Western Europe," and called for French action towards European integration ${ }^{56}$. He wrote in the letter to them: "I have in mind a timetable for the creation of supra-national institutions, operating on a less than unanimity basis for dealing with specific, economic, social and perhaps other problems ${ }^{57 "}$. What the United States described was a kind of a very strong federal system or supra-nationalism: "A single market involving the free movement of goods, services and capital ${ }^{58 ”}$.

The partnership between France and Germany had to be the first step in the creation of a united Europe as British Prime minister, Winston Churchill emphasized in his speech at Zurich University on September 19, 1946. "In this way only can France recover the moral leadership of Europe. There can be no revival

53 Nicoll W., Salmon T.C., Understanding the New Europe Community, 2nd ed., New York : Prentice Hall/Harvester Wheatsheaf, 1994, p. 12.

54 See Goldsborough J., "The Franco-German Entente", Foreign Affairs, 54 (3), 1976; Storey J., "The Franco-German Alliance within the European Community", World Today, 1980.

55 Wallace W., Introduction to Roger Morgan and Caroline Bray, Partners and Rivals in Western Europe: Britain, France and Germany, Brookfield: Gower, 1986, p. 4.

56 Milward A.S., The Reconstruction of Western Europe, 1945-1951, London: Newton, 1984, p. 391.

57 Telegram from Dean Acheson to the US Embassy in Paris, Washington, 19 October, 1949, <http:// www.cvce.eu/obj/telegram_from_dean_acheson_to_the_us_embassy_in_paris_washington_19_ october_1949-en-ef456d4c-b0cc-4a98-a496-586b8ccb19b5.html>, 16122013.

58 Dinan D., Europe Recast: A History of the European Union, London: Lynne Reinner Publishers, 2004; Eichengreen B., Kenen P., "Managing the world economy under the Bretton Woods system: An overview", in Kenen P., eds., Managing the world economy: Fifty years after Bretton Woods, Washington, DC: Institute for International Economics, 1994, p. 26. 
of Europe without a spiritually great France and a spiritually great Germany. The structure of the United States of Europe, if well and truly built will be such as to make the material strength of a single state less important... In all this urgent work, France and Germany must take the lead together ${ }^{59}$.

On May 9, 1950, the French Foreign Minister, Robert Schuman, argued for European economic integration as a way to rapprochement between France and Germany, and proposed the Schuman Plan. The fundamental scheme was to create a supra-national High Authority to take control of the coal and steel industries of France, Germany and any other states that wished to join.

This, Schuman stated, would "make war not merely unthinkable but materially impossible ${ }^{60}$. On April 18, 1951, the Treaty of Paris was signed, creating the European Coal and Steel Community (ECSC). Six nation-states: France, Germany, Italy, Belgium, the Netherlands and Luxembourg made up this first European Community. The objectives of the Treaty, as stipulated in Article 2, were to make contribution, through the common market for coal and steel, to economic development, increase in employment and improvement of living standards:

The European Coal and Steel Community shall have as its task to contribute, in harmony with the general economy of the Member States and through the establishment of a common market [...] to economic expansion, growth of employment and a rising standard of living standard in the Member States ${ }^{61}$.

In the light of the formation of the common market, the free movement of products without customs duties or taxes was introduced. This put an end to discriminatory measures or practices, subsidies, aids granted by States or special charges imposed by States and restrictive practices. Evidently, the ECSC could be understood as an international community on the premise of supra-nationalism and international law, formed to help the European economy and prevent future wars by integrating its member states as stated in the Schuman Declaration:

It proposes that Franco-German production of coal and steel as a whole be placed under a common High Authority, within the framework of an

\footnotetext{
59 Winston Churchill's speech on a Council of Europe, Zurich University, September 19, 1946, <http://aei.pitt.edu/14362/1/S2-1.pdf>, 27012014.

60 Declaration [on French proposal to place coal and steel under "higher authority"] by French Foreign Minister Robert Schuman, Paris, May 9, 1950, <http://aei.pitt.edu/14363/>, 16092013.

${ }_{61}$ Treaty of Paris, April 18, 1951, <http://www.proyectos.cchs.csic.es/euroconstitution/library/histo ric\% 20documents/Paris/TRAITES_1951_CECA.pdf>, 22122013.
} 
organization open to the participation of the other countries of Europe. The pooling of coal and steel production should immediately provide for the setting up of common foundations for economic development as a first step in the federation of Europe ${ }^{62}$.

The very first supra-national organization of Europe began work in August 1952 and was governed by four institutions: A High Authority, a Special Council of Ministers, a Common Assembly and a Court of Justice.

The US attitudes and views towards the formation of the ECSC were positive and constructive. The United States favoured the French efforts and considered the Schuman Plan as the most significant step towards economic prosperity and peace in Europe since the Marshall speech on the ERP. According to Secretary of State Acheson, the ECSC was a community that could offer reconciliation and cooperation.

Monnet [was] most anxious that this proposal be accepted as a significant far-reaching effort not only toward Franco-German understanding but European federation and not viewed as an expedient or trick by which France could gain any particular advantage on the continent. [...] In commenting on [the] proposal believe it is important that [the] French be given credit for making a conscious and far reaching effort to advance Franco-German rapprochement and European integration generally ${ }^{63}$.

The United States considered the birth of the ECSC as a means to unify Europe and preserve lasting peace as indicated in President Eisenhower's letter to chairmen of senate foreign relations and house foreign affairs committees on June 151953.

While in Europe, I watched with keen interest the efforts to work out the first steps toward European federation. My experience there convinced me that the uniting of Europe is a necessity for the peace and prosperity of Europeans and of the world.

[...] This Community (the ECSC) seems to me to be the most hopeful and constructive development so far toward the economic and political integration of

62 The Schuman Plan Declaration, May 9, 1950 [Translation of the text of Schuman's radio announcement of a French-German pool for coal and steel], < http://www.let.leidenuniv.nl/pdf/ geschiedenis/eu-history/EU_06.doc>, 24122013.

63 Acheson D., The Secretary of State to the Acting Secretary of State, May 10, 1950, <www.let. leidenuniv.nl/pdf/geschiedenis/eu-history/EU_07.doc>, 20052013. 
Europe. As such, this European initiative meets the often-expressed hopes of the Congress of the United States ${ }^{64}$.

That both Germany and France mutually re-emerged and cooperated was a chance for the hopes often expressed by US leaders to be realized. European federation would help to diminish the need of the United States to guarantee peace in Europe. In the mind of US leaders, this very community was also seen as a potential and essential ally against the Soviet Union. That seemed to be what the United States were deeply concerned over. Although there was also a fear of the formation of a cartel by France, which might cause conflicts with the interests of the United States, Washington soon overcame that fear ${ }^{65}$. Moreover, the split between France and the United Kingdom continued to concern US leaders and Britain's refusal to join the ECSC was criticized.

\section{Concerted efforts: the European Economic Community and the European Atomic Energy Community}

Due to energy crises, the Common Assembly put forward a proposal of extending the powers of the ECSC to cover other sources of energy. However, Jean Monnet, the chief architect of European unity, wanted a separate community to cover nuclear power. Louis Armand was given a task to study the prospects of nuclear energy use in Europe. His report concluded that further nuclear development was essential to fill the shortage left by the exhaustion of coal deposits and to decrease dependence on oil producers. However, the Benelux states and Western Germany were also enthusiastic about initiating a general common market, as sectoral integration, they claimed, had its weaknesses: "In the last four years the Coal and Steel Community has proved that the common market is not only feasible but, on balance, advantageous for all concerned. But it has also shown that "integration by sector" raises its own problems of distortion and discrimination. The Benelux, Western Germany and Italy had therefore chosen to create a common market for

${ }^{64}$ Eisenhower D. D., Letter to Chairmen of Senate Foreign Relations and House Foreign Affairs Committees Concerning the European Coal and Steel Community, June 17, 1953, online by Gerhard Peters and John T. Woolley, The American Presidency Project, <http://www.presidency. ucsb.edu/ws/?pid=9614>, 21012014.

65 Acheson D., Present at the creation: My years in the state department, New York: W.W. Norton \& Company, 1969, p. 383. 
all products rather than continuing to experiment with the sector approach ${ }^{66 "}$. Unfortunately, France was strongly against this because of its protectionism and Jean Monnet supposed that it was too ambitious. In an effort to satisfy all interests, Jean Monnet ultimately put forth the proposal of creating both as separate communities.

Following the Treaty of Paris, the signing in Rome of the Treaties in 1957 setting up the European Economic Community (EEC) and the European Atomic Energy Community (EAEC or Euratom) has been viewed as a crucial stage in the history of European integration. The EEC established a general common market featuring a customs union, which was based both on the free movement of goods, persons, services and capital and common policies. Only one year after the official creation of the EEC, there were tariff deductions and quota increases in the early practical move to the economic union of Europe. The United States and European leaders highly hoped that the EEC would be much more than simply a customs union. Expectedly, it would be a vehicle that could provide the impetus for full integration in Europe. The EEC had to work out common policies for agriculture, transport, and foreign trade. Additionally, it had to bring into effect common economic, financial, monetary, and labor policies. In essence, the EEC was leading the road to both political and economic integration as its leaders put forth with particular vigor:

We look upon the Common Market, the Coal and Steel Community, and Euratom as a single unit. They are all aspects of a process of development, which in the end should lead to a politically united Europe. Our aim is a free and peaceful Europe, a Europe worth living in and able to attract all European peoples who can freely determine their own destiny ${ }^{67}$.

When having a meeting with Dr. Walter Hallstein, President of the Commission of the European Economic Community at the White House on May 16, 1961, President Kennedy reemphasized the US government's strong assistance for the EEC and the course of the European integration as outlined in the Treaty of Rome. President Kennedy held the view that the European integration process of the six signatory nations of the Treaty of Rome constituted a complementary driving force for the development of the Atlantic community. Also, President Kennedy expressed the US wish to have a common agricultural policy within the EEC.

66 George S., Bache I., Politics in the European Union, Oxford: Oxford University Press, 2001, p. 72.

67 “Three Presidents on Official Visit to U.S.", Bulletin from European Community, Special Issue, 1959, <http://aei.pitt.edu/43616/1/A7420.pdf>, 12122013. 
Continually, in his "Annual Message to the Congress on the State of the Union," on January 4, 1965 President Lyndon B. Johnson showed the US government's high hope of a strong and united Europe that would be in cooperation with the United States. European integration, in President Johnson's perspective, was not built on any abstract design. It was created and developed on the basis of "the realities of common interests and common values, common dangers and common expectations ${ }^{68}$ ". In addition to ensuring Dr. Hallstein of the continued strong support of the US for the goal of European unification, President Johnson embraced European leaders' decision to merge the executive bodies of the three European Communities (the ECSC, the EEC and the Euratom) as a further essential step in the European integration process.

Regarding Euratom, its first pact for cooperation was linked with the United States. In this 25-year agreement, Washington provided a long-term credit of $\$ 135$ million to the EEC to purchase reactors and nuclear components, which would be used to build atomic-power plants within the Community. Moreover, the United States offered an amount of US $\$ 90$ million for fuel guarantees and pledged to give $\$ 50$ million for research and development over the first five-year period. The United States-Euratom agreement for cooperation was an indication of Washington's consistent supports to European leaders' efforts to strengthen unity in the continent. Euratom, dedicated to the civil importance of atomic energy, initiated a common nuclear market: "Euratom's very name is significant, for it couples in a single word two of the revolutionary changes brought about in the 20 th century. The first is the new industrial revolution unleashed by the peaceful application of nuclear energy. The second is the economic and political revolution that is leading toward the unity of Europe ${ }^{69}$.

Roughly five years after the Treaty of Paris establishing the ECSC came into effect; Western Europe took an irreversible step forward towards integration. There was no doubt about the US's continued support for more comprehensive forms of European integration. Washington was particularly satisfied that Western European leaders had recognized the need for their countries to continue to advance "beyond cooperative arrangements to Federal institutions, with necessary transfer of sovereign power ${ }^{70}$. The United States encouraged and supported Germans and other Europeans advocating such views. The US ambitions of 1947-1949 for a

68 Johnson L. B., Annual Message to the Congress on the State of the Union, January 4, 1965, online by Gerhard Peters and John T. Woolley, The American Presidency Project, <http://www.presidency. ucsb.edu/ws/?pid=26907>, 16092013.

69 Three Presidents on Official Visit, (note 67).

70 Lundestad G., Empire' by Integration: The United States and European Integration, 1945-1997, Oxford: Oxford University Press, 1998, p. 49. 
customs union under the OEEC were basically similar to the European common market concept expressed in the Treaty of Rome in 1957. Thus, in principle the United States had a very favourable attitude towards the creation of the EEC. President Eisenhower publicly announced the US's full support for a European common market that would further speed up the economic integration of Western Europe in his speech in Miami, Florida, on October 29, 1956:

Nothing has been more heartening than the recent announcement of two new proposals that would advance further the economic integration of Europe.

The first is the concept that six Western European countries might establish a common market in which all internal barriers to trade would be completely eliminated, just as they are within the United States. The second is the challenging idea that, thereafter, Great Britain, in association with other countries on the European Continent might gradually, over a period of years, establish a free trade area around the common market ${ }^{71}$.

Despite its keen interest in the founding of the EEC, the Eisenhower administration realized this new and crucial advancement of European integration might pose such challenges as the discriminatory effects of the EEC and the consequences on the balance of trade. But President Eisenhower and the State Department supposed that when the US economy was in a good condition, it was unproblematic for Washington to confirm that the European integration process could be worth certain economic sacrifices ${ }^{72}$. Like US views towards European integration in the Eisenhower administration, US support for the EEC remained enthusiastic and consistent in the Kennedy and Johnson administrations as shown respectively in their joint statements with Dr. Hallstein, the President of the Commission of the European Economic Community.

The President and Dr. Hallstein were in full agreement that the European integration movement of the six signatory countries of the Treaty of Rome complements and reinforces the progressive development of a true Atlantic Community $^{73}$.

71 Eisenhower, D. D., Address at the International Airport, Miami, Florida, October 29, 1956, online by Gerhard Peters and John T. Woolley, The American Presidency Project, <http://www.presidency. ucsb.edu/ws/?pid=10680>, 22012014.

72 Coppolaro L., Trade, Security and GATT: The United States, Western Europe and the Political Economy of Trade Liberalisation (1947-1972), University of Lisbon, 2010.

73 Kennedy J. F., Joint Statement Following Meeting With Dr. Walter Hallstein, President of the European Economic Community, May 16, 1961, online by Gerhard Peters and John T. Woolley, The American Presidency Project, <http://www.presidency.ucsb.edu/ws/?pid=8132>, 21012014. 
The President and Dr. Hallstein agreed on the high value of existing close relations between the United States and the Common Market. They agreed that continued progress toward European integration strengthens the free world, as European partnership with the United States grows closer.

President Johnson assured Dr. Hallstein of the continued strong support of the United States for the goal of European unity. The President extended his congratulations on the recent decision to merge the executive bodies of the three European Communities, which the President sees as another significant step in the process of European integration ${ }^{74}$.

During the mid-1960s, there were a number of crises in the EEC. The root cause was General de Gaulle's policy on Europe: He tried to enhance France's position in the EEC by keeping the latter's supra-national power to a minimum. Instead, he sought to pursue intergovernmental cooperation among member states. In addition, tensions increased between France and the Five because of the failure of the Fouchet Plan for a "Union of States" in 1962 and France's refusal of the British application for accession to the Common Market in 1963. However, such tensions could not deny the fact that the Six still attempted to settle on an appropriate roadmap for European integration.

In summary, the Treaty of Paris and the Treaty of Rome leading to the creation of the ECSC, the EEC and Euratom were strong indications of the early concrete achievements of the European integration process. Politically and economically, the launch of the ECSC, EEC and Euratom was a major historical event. It was the firm foundation for the development of "the European Family." The coming together of the European countries helped eliminate the old-time opposition of France and Germany and move definitively away the ghost of war on the European continent as Robert Marjolin recalled in his memoirs: "who would have thought during the 1930s, and even during the ten years that followed the war, that European states which had been tearing one another apart for so many centuries and some of which, like France and Italy, still had very closed economies, would form a common market intended eventually to become an economic area that could be linked to on great dynamic market ${ }^{75}$. The process leading to the formation of both the ECSC and the EEC was enthusiastically encouraged by the United States as it had been implemented within the Atlantic framework that US governments outlined. With its Marshall Plan aid and participation in NATO,

\footnotetext{
74 Johnson, (note 68).

75 Marjolin R., Architect of European Unity: Memoirs, 1911-1986, London: Weidenfeld \& Nicolson, 1989, p. 306.
} 
the United States was a leading contributor to the peace, security and economic recovery in Western Europe. The vitality of the European integration project depended on US economic and political capital for its success.

\section{Conclusion}

With a historical approach, this article has demonstrated that the US policy on Europe from 1945 to 1968 was built on Washington's endorsement of developing Western Europe into a regional union based on the US socio-economic and political model. U.S. leaders from the Truman to Johnson presidential periods made fundamental decisions to rehabilitate Western Europe economically and build up its confidence politically. Their policy stance was clear: The best way to achieve stability in Europe was by uniting Europe. From the Marshall Plan, the creation of NATO, through to the promotion for the births of the ECSC and the EEC, the United States had consistently shown its willingness to expend its wealth, and even its troops, to bring peace and prosperity to Europe. Explicitly, this meant that the United States could not live in isolation. 